\section{Horticultural and Economic Impact of Rootstocks on Fresh-market 'Marsh' Grapefruit}

\author{
William S. Castle ${ }^{1}$ \\ University of Florida, IFAS, Horticultural Sciences Department, Citrus \\ Research and Education Center, 700 Experiment Station Road, Lake Alfred, \\ FL 33850
}

Additional index words. 1584 Poncirus trifoliata $\times$ Milam hybrid, C-35 citrange, Citrus paradisi, crop value, fruit size distribution

\begin{abstract}
A rootstock trial with a 'Marsh' grapefruit (Citrus paradisi Macf.) scion was established in the flatwoods of the Florida east coast Indian River region in 1990. The trees were planted in an Alfisol of the Pineda series. The trial consisted of trees on 16 rootstocks, primarily citranges $[C$. sinensis $(\mathrm{L}$.$) Osb. \times$ Poncirus trifoliata (L.) Raf.], citrumelos $(C$. paradisi $\times P$. trifoliata $)$, mandarins $(C$. reticulata Blanco) and various hybrids, in three or six replicates of three-tree plots in a randomized complete block design. Tree growth and survival, yield, and juice quality were measured annually or periodically for 10 years. In three seasons, whole-tree crops were sized in the field. Using the fruit size distribution data, crop value or income/tree was estimated. Tree height after 10 years ranged from 1.7 to $4.1 \mathrm{~m}$ and survival was greater than $90 \%$ with a few exceptions. Mean cumulative yield was $1202 \mathrm{~kg} /$ tree and ranged from 649 (Hamlin + Flying Dragon trifoliate orange) to $1615 \mathrm{~kg} /$ tree for a hybrid of trifoliate orange $\times$ Milam. At tree age 9 years, mean soluble solids production was $3594 \mathrm{~kg} \cdot \mathrm{ha}^{-1}$ with a $240 \%$ difference between the lowest and highest value. There were differences in the distribution of four commercial-sized categories based on analysis of individual sizes and using PROC FREQ to examine and compare whole-tree distributions. When the yield and fruit size data were combined for 3 years and converted to income/tree using commercial Florida Freight On Board prices in November and March, the trees on a trifoliate orange $\times$ Milam hybrid (1584) had the highest estimated income (\$354 U.S., March data) followed by Calamandarin (\$321) and Norton citrange (\$292). The lowest income/tree was $\$ 112$ (Hamlin + Flying Dragon trifoliate orange). When all data were considered, the best matches to current grower interest in smaller sized trees, and high yield and fruit quality, were the hybrid 1584 and C-35 citrange rootstocks.
\end{abstract}

The Florida grapefruit industry built its reputation largely on fresh fruit grown in the Indian River region along the east coast (Stover and Castle, 2002). The particular combination of soils, climate, and the use of sour orange $(C$. aurantium L.) rootstock resulted in the production of fruit with high external and internal quality. Trees on sour orange rootstock are well known for producing excellent quality fruit and for thriving well in many challenging types of sites related to soils and drainage that exist in the Indian River region. However, in recent years, the importance of sour orange declined because of continuing problems with citrus tristeza virus (CTV), which was exacerbated with the arrival of the efficient insect vector, the brown citrus aphid, Toxoptera citricida (Kirkaldy), in 1995. Growers need information about alternative rootstocks to replace sour orange. Attempts to discover other rootstocks with qualities equal or sufficiently similar to those of sour orange have not been

Received for publication 23 Apr. 2012. Accepted for publication 11 June 2012.

${ }^{1}$ To whom reprint requests should be addressed; e-mail bcastle@ufl.edu. known among Florida grapefruit growers and packers that Japanese buyers impose high standards on both internal and external (fruit size) quality. Thus, there is a continuing need to identify and evaluate suitable rootstocks that are tolerant of CTV, thrive under a range of soil conditions, and induce good fruit quality, especially high soluble solids concentration and fruit sizes. The objectives of this study were to evaluate a series of rootstocks for tree growth, fruit internal quality, yield, whole-tree fruit size distribution, and to conduct an economic interpretation of those combined data from a freshmarket perspective.

\section{Materials and Methods}

Plant material and propagation. The rootstocks were mostly citranges plus a few commercial rootstocks and somatic and other hybrids (Table 1). Sour orange was not included because of the risk of CTV. Nursery trees were produced in a commercial nursery using rootstock seeds provided from certified local sources. Seedlings were budded with 'Marsh' grapefruit scion, clone F574-X-E, for which the budwood source had been tested for viruses and viroids and no CTV, xyloporosis (X), or exocortis (E) was detected.

Field trials. The commercial field site (lat. $27^{\circ} 27^{\prime} 13.46^{\prime \prime}$; long. $80^{\circ} 33^{\prime} 58.83^{\prime \prime}$; elevation, $7.3 \mathrm{~m}$ ) was located west of Fort Pierce, FL, and had been planted with citrus that was removed about 1 year before planting this trial. The soil series at the site was mapped as Pineda, an Alfisol in the family of Arenic Glossaqualfs. The surface $15 \mathrm{~cm}$ is dark brown sand underlain by 30 to $50 \mathrm{~cm}$ of a brownish yellow argillic horizon. At the south end of the trial area was Riviera, a closely related series, but with the clay or argillic layer usually closer to the surface than in soils of the Pineda series. The south end of the site was not as well drained and was generally wetter, which negatively influenced tree performance.

The site was typical of the Indian River region in that drainage was provided by dredging perimeter ditches. Shallow furrows were excavated in the planted area and the soil used to form double-row beds on which the trees were planted. Such beds are typically $\approx 15 \mathrm{~m}$ wide and 0.5 to $1 \mathrm{~m}$ above the natural landscape. Trees on 16 rootstocks were planted $4.6 \mathrm{~m}$ in the row and $6.7 \mathrm{~m}$ between rows in Sept. 1990 in a randomized complete block design with six replicates of 14 rootstocks and three replicates of four rootstocks in three-tree plots in the tree row. The different number of replicates was the result of space limitations and tree availability. The trees on a few rootstocks were not planted until Mar. or Sept. 1991. The trial was irrigated with a microsprinkler system, which also provided cold protection. The trees were cultured with local standards for fresh fruit including regular fertilization with dry materials at the annual rate of $\approx 180 \mathrm{~kg} \cdot \mathrm{ha}^{-1}$ (Obreza and Morgan, 2008; Rogers et al., 
2012). The trees were topped mechanically every $\approx 2$ to 3 years at 4 to $5 \mathrm{~m}$ height. At the time of this trial, citrus canker was just becoming a problem but did not affect the conduct of the trial and Huanglongbing had not yet been discovered in Florida.

Data collection and analysis. Tree height was measured in 1994, 1997, and 2001 along with tree survival. Annual samples of 50 fruit were collected from each plot near the time of harvest. Juice was extracted and analyzed with standard commercial equipment at the Citrus Research and Education Center, Lake Alfred (Wardowski et al., 1995). Fruit yield was measured annually with a commercial harvesting crew by placing fruit in a commercial field container holding $385 \mathrm{~kg}$ and recording volume in boxes, the standard commercial unit of yield which when filled with fruit weighs $\approx 38.5 \mathrm{~kg}$. Yield in the 1998 1999 (tree age 8 years), 1999-2000 (9 years), and 2002-2003 (12 years) seasons was measured by harvesting the entire crop on each tree and placing it on a portable packing line (Autoline ProSort II sizer; Autoline, Inc., Reedly, CA) that measured the size and calculated the weight of each fruit. It has the same cameras, fruit cups, weight sensors, software, and logic boards as commercial packing lines. Fruit from each tree were placed in a hopper and transferred in a single line to the camera for measurement. The software accumulated the number of fruit in each of the defined fruit sizes based on parameters set up by the user. Fruit size is the maximum diameter of the fruit. Fruit sizes were separated based on 3-mm increments. The packing line and software were set to divide the fruit into a maximum of 14 size categories with some overlap in all the fruit sizes. The fruit were separated into the various sizes to closely correspond to the midpoint of the overlap between official Florida Department of Citrus fruit sizes. The sizes for our study were based on the number of fruit packed into a standard commercial cardboard carton that holds $\approx 20 \mathrm{~kg}$ of fruit: small (48 or more fruit/carton), medium (40 and 48), large (32 and 36), and extra large (27 or fewer fruit/ carton). For Florida export fresh grapefruit, the desired sizes are 32 or 36 (Japan) and 40 or 48 (Canada).

Data analyses were according to the randomized complete block design using PROC GLM with mean separation by the least significant difference test. Some variables were examined by simple linear correlation analysis at $* P \leq 0.05 * * * 0.01$, or $* * * 0.001$. Three years of fruit size data $(1998-1999,1999$ 2000, and 2002-2003 seasons) were analyzed for differences among rootstocks for each individual packing size and the overall distributions. PROC GLM was used to compare differences among rootstocks and for each fruit size class and year using arcsine transformed percentages. Fruit size distributions/ tree were examined using PROC FREQ in each of the 3 years (Louzada et al., 2008). Rootstock was a significant factor in each year, but rather than examining all possible pairs of distributions in each year,

Table 1. Height $(n=6)$ of 'Marsh' grapefruit trees grown in the Florida Indian River region on various rootstocks and tree survival at age 10 years. ${ }^{2}$

\begin{tabular}{|c|c|c|c|c|}
\hline \multirow[b]{2}{*}{ Rootstock } & \multicolumn{3}{|c|}{ Tree ht $(\mathrm{m})$ at age } & \multirow[b]{2}{*}{ Survival (\%) } \\
\hline & $3 \mathrm{yrs}$ & $6 \mathrm{yrs}$ & $10 \mathrm{yrs}$ & \\
\hline Calamandarin $^{y}$ & 2.4 & 3.7 & 4.1 & 94 \\
\hline $\begin{array}{l}\text { Citrus madurensis } \\
\quad \text { (Lour.) } \times \text { C. reticulata } \text { Blanco }\end{array}$ & & & & \\
\hline $\begin{array}{l}\text { Cleopatra mandarin } \\
\text { C. reticulata }\end{array}$ & 2.4 & 3.7 & 4.1 & 100 \\
\hline $\begin{array}{l}\text { Ridge Pineapple sweet orange } \times \text { trifoliate } \\
\text { orange }(1578-173)^{\mathrm{x}, \mathrm{w}} \\
\quad \text { C. sinensis }(\mathrm{L} \text {.) Osb. } \times \text { Poncirus trifoliata } \\
\quad \text { (L.) Raf. }\end{array}$ & 2.5 & 3.6 & 4.1 & 0 \\
\hline $\begin{array}{l}\text { Murcott } \\
\text { C. reticulata } \times \text { C. sinensis }\end{array}$ & 2.4 & 3.9 & 4.1 & 100 \\
\hline $\begin{array}{l}\text { Minneola tangelo } \times \text { trifoliate orange } \\
{[\text { C. paradisi (Macf.) 'Duncan' } \times} \\
\text { C. reticulata 'Dancy'] } \times \text { P. trifoliata }\end{array}$ & 2.3 & 3.6 & 3.8 & 67 \\
\hline $\begin{array}{l}\text { Sun Chu Sha mandarin }{ }^{\mathrm{w}, \mathrm{v}} \\
\text { C. reticulata }\end{array}$ & 2.1 & 3.1 & 3.5 & 67 \\
\hline $\begin{array}{l}\text { Swingle citrumelo } \\
\quad \text { C. paradisi } \times P \text {. trifoliata }\end{array}$ & 2.4 & 3.0 & 3.4 & 94 \\
\hline $\begin{array}{l}\text { Norton citrange } \\
\quad \text { C. sinensis } \times P \text {. trifoliata }\end{array}$ & 2.3 & 3.2 & 3.4 & 100 \\
\hline $\begin{array}{l}\text { Carrizo citrange } \\
\quad \text { C. sinensis } \times \text {. trifoliata }\end{array}$ & 2.3 & 3.1 & 3.2 & 100 \\
\hline $\begin{array}{l}\text { Trifoliate orange } \times \text { Milam }(1584) \\
\quad \text { P. trifoliata } \times \text { C. jambhiri 'Milam' }\end{array}$ & 2.1 & 3.1 & 3.2 & 94 \\
\hline $\begin{array}{l}\text { Benton citrange } \mathrm{e}^{\mathrm{w}, \mathrm{v}} \\
\quad \text { C. sinensis } \times P \text {. trifoliata }\end{array}$ & 2.3 & 2.9 & 3.1 & 100 \\
\hline $\begin{array}{l}\text { Morton citrange } \\
\text { C. sinensis } \times P \text {. trifoliata }\end{array}$ & 2.3 & 2.9 & 3.1 & 100 \\
\hline $\begin{array}{l}\text { C-35 citrange } \\
\text { C. sinensis } \times P \text {. trifoliata }\end{array}$ & 2.2 & 2.9 & 2.9 & 94 \\
\hline $\begin{array}{l}\text { Trifoliate orange } \times \text { Milam }(1572) \\
\quad \text { P. trifoliata } \times \text { C. jambhiri 'Milam' }\end{array}$ & 2.0 & 2.8 & 2.9 & 50 \\
\hline $\begin{array}{l}\text { Ridge Pineapple } \times \text { trifoliate orange }(1575-21)^{\mathrm{x}, \mathrm{w}} \\
\text { C. sinensis } \times P \text {. trifoliata }\end{array}$ & 2.1 & 2.5 & 2.8 & 0 \\
\hline $\begin{array}{l}\text { Hamlin }+ \text { Flying Dragon trifoliate orange } \\
\text { C. sinensis } \times \text { P. trifoliata }\end{array}$ & 1.8 & 2.2 & 2.3 & 100 \\
\hline $\begin{array}{l}\text { Hamlin }+S \text {. disticha } \\
\text { C. sinensis } \times \text { Severinia disticha (Blanco) } \\
\quad \text { Swing. }\end{array}$ & 2.0 & 2.1 & No data & 0 \\
\hline $\begin{array}{l}\text { Trifoliate orange } \times \text { Ridge Pineapple }(1573-26) \\
\quad \text { P. trifoliata } \times \text { C. sinensis }\end{array}$ & 1.9 & 1.7 & No data & 0 \\
\hline Mean & 2.2 & 3.0 & 3.4 & \\
\hline Least significant difference & 0.2 & 0.4 & 0.4 & \\
\hline
\end{tabular}

${ }^{2}$ Trees were planted Sept. 1990 at $4.6 \times 6.7 \mathrm{~m}$. Rootstocks are sorted by tree height at age 10 years. ${ }^{\mathrm{y}}$ The classification of this rootstock is unclear. See this web site for additional information: $<\mathrm{http}: / /$ www.citrusvariety.ucr.edu/citrus/sunchushakat.html $>$.

xPlanted Sept. 1991.

${ }^{\mathrm{w}}$ Only nine trees in three replicates.

vPlanted Mar. 1991.

Table 2. Seasonal 'Marsh' grapefruit Freight on Board prices (U.S. dollars) for fruit harvested in the Florida Indian River region. ${ }^{\mathrm{z}}$

\begin{tabular}{lccccccccc}
\hline Week & & \multicolumn{7}{c}{ No. fruit/20-kg shipping carton } & Weighted \\
\cline { 3 - 9 } ending & Season & \multicolumn{1}{c}{23} & \multicolumn{1}{c}{27} & \multicolumn{1}{c}{32} & \multicolumn{1}{c}{36} & \multicolumn{1}{c}{40} & 48 & 56 & \multicolumn{1}{c}{ avg } \\
\hline 19 Nov. & $2006-2007$ & 14.00 & 14.00 & 14.00 & 12.00 & 10.00 & 9.00 & No data & 12.46 \\
& $2007-2008$ & 15.00 & 15.00 & 15.00 & 13.00 & 11.00 & 9.00 & No data & 13.30 \\
& $2008-2009$ & 12.00 & 12.00 & 10.50 & 9.50 & 8.50 & 7.00 & No data & 10.76 \\
& $2009-2010$ & 17.00 & 17.00 & 15.00 & 12.00 & 10.50 & 9.00 & 8.00 & 14.76 \\
& $2010-2011$ & 17.50 & 17.50 & 15.00 & 13.50 & 11.00 & 7.00 & 6.00 & 14.87 \\
& Mean & 15.10 & 15.10 & 13.90 & 12.00 & 10.20 & 8.20 & 7.00 & 13.23 \\
4 Mar. & $2006-2007$ & 11.00 & 11.00 & 11.00 & 10.00 & 9.25 & 8.25 & No data & 10.58 \\
& $2007-2008$ & 10.00 & 10.00 & 10.00 & 8.50 & 7.50 & 7.00 & No data & 9.38 \\
& $2008-2009$ & 10.00 & 10.00 & 10.00 & 8.50 & 8.00 & 7.00 & No data & 9.38 \\
& $2009-2010$ & 14.00 & 14.00 & 12.00 & 10.50 & 9.50 & 7.50 & 6.50 & 11.88 \\
& $2010-2011$ & 12.00 & 13.00 & 13.00 & 10.00 & 9.50 & 6.00 & 6.00 & 12.54 \\
& Mean & 11.40 & 11.60 & 11.20 & 9.50 & 8.75 & 7.15 & 6.25 & 10.75 \\
\hline
\end{tabular}

${ }^{\mathrm{z}}$ Data from the Florida Citrus Administrative Committee. $<$ http://www.citrusadministrativecommittee. $\operatorname{org} />$.

a representative season (2002-2003) was selected. A few comparisons illustrating differences among rootstocks were conducted after a visual inspection of the data. The economic impact of fruit size distribution was assessed by calculating crop value or 
total income/tree using Freight On Board (FOB) price data collected by the Florida Citrus Administrative Committee (<http:// www.citrusadministrativecommittee.org/>) for Indian River-grown white grapefruit packed in commercial fruit sizes in $20-\mathrm{kg}$ cartons. Data from the first week of March were recommended as representative in the five seasons of 2006-2007 through 2010 2011, but crop value was also calculated for November, a time in each season when fruit prices for the larger sizes were higher (Table 2 ). The number of fruit of each size of each rootstock and year was converted to carton equivalents and multiplied by the five-season mean FOB price for a given fruit size. Because the trial fruit size data were placed into size groups rather than individual sizes, some interpolation of the price data was necessary. The income/tree or crop value was the amount summed across all fruit size groups and the three seasons. Income/tree data were subjected to an analysis of variance with mean separation by the least significant difference procedure.

\section{Results and Discussion}

Tree height and survival. After 3 years, mean tree height was $2.2 \mathrm{~m}$ and ranged from 1.8 to $2.5 \mathrm{~m}$ (Table 1 ). The relationship among rootstocks remained virtually the same as the trees aged so that after 10 years, the tallest trees were those on such rootstocks as Cleopatra mandarin and Murcott at $4.1 \mathrm{~m}$. The smallest trees included those on C-35 citrange $(2.9 \mathrm{~m})$ and a 'Hamlin' sweet orange + Flying Dragon trifoliate orange somatic hybrid $(2.2 \mathrm{~m})$. Tree survival after 10 years was $90 \%$ to $100 \%$ among the trees on most rootstocks except for the 1578-173, 1573-26, 157521, and 1572 hybrids in which many trees succumbed to Phytophthora foot rot. Those hybrids were produced by Harry Ford (retired, Citrus Research and Education Center) for their tolerance to burrowing and citrus nematodes. Similar problems with Phytophthora were encountered in other trials (Castle and Baldwin, 2008). The trees on Hamlin + $S$. disticha grew off weakly and were unthrifty in appearance.

Fruit yield. The trees began to bear a commercial crop in their second year (Table 3). At that time, the mean yield was $32 \mathrm{~kg}$ / tree with the trees on $\mathrm{C}-35$ and Morton citranges bearing greater than $50 \mathrm{~kg} /$ tree. No adjustments were made for differences in tree age; thus, yield in the first years was relatively low among the trees on Benton citrange and Sun Chu Sha mandarin because they were planted 6 months later. However, their yields lagged behind for only $\approx 1$ year among the trees on Benton citrange and for a longer period on Sun Chu Sha. The trees on 1578-173 and 1575-21 were planted 12 months after the trial was established, but their yields also only lagged no more than $\approx 1$ year.

Annual yields increased steadily until the trees were $\approx 7$ to 8 years old and then the trees on some rootstocks displayed a more evident tendency toward alternate bearing. Peak yield

Table 3. Yield ( $\mathrm{kg} /$ tree; $\mathrm{n}=6$ ) of 'Marsh' grapefruit trees on various rootstocks planted in Sept.1990 in the Florida Indian River region at $4.6 \times 6.7 \mathrm{~m}$.

\begin{tabular}{|c|c|c|c|c|c|c|c|c|c|c|c|}
\hline \multirow[b]{2}{*}{ Rootstock } & \multicolumn{10}{|c|}{ Tree age $(\mathrm{yrs})^{\mathrm{z}}$} & \multirow{2}{*}{$\begin{array}{l}\text { Cumulative } \\
\text { yield }\end{array}$} \\
\hline & 2 & 3 & 4 & 5 & 6 & 7 & 8 & 9 & 11 & 12 & \\
\hline $\begin{array}{l}\text { Trifoliate orange } \times \text { Milam } \\
(1584)\end{array}$ & 47 & 78 & 100 & 124 & 173 & 198 & 188 & 255 & 210 & 242 & 1615 \\
\hline C-35 citrange & 59 & 105 & 112 & 159 & 193 & 170 & 160 & 206 & 137 & 155 & 1456 \\
\hline Calamandarin & 22 & 60 & 66 & 109 & 176 & 192 & 179 & 266 & 176 & 157 & 1403 \\
\hline $\begin{array}{l}\text { Ridge Pineapple } \times \text { Milam } \\
\quad(1578-173)^{\mathrm{y}}\end{array}$ & 10 & 57 & 77 & 140 & 178 & 227 & 163 & 184 & 166 & 133 & 1400 \\
\hline Murcott & 24 & 69 & 108 & 115 & 149 & 206 & 180 & 276 & 157 & 66 & 1349 \\
\hline Norton citrange & 43 & 83 & 70 & 125 & 152 & 136 & 164 & 204 & 172 & 182 & 1331 \\
\hline Swingle citrumelo & 42 & 79 & 105 & 122 & 151 & 168 & 149 & 209 & 175 & 126 & 1327 \\
\hline Cleopatra mandarin & 31 & 70 & 84 & 108 & 142 & 205 & 158 & 204 & 169 & 96 & 1266 \\
\hline Morton citrange & 51 & 91 & 132 & 125 & 154 & 154 & 140 & 187 & 138 & 80 & 1251 \\
\hline Benton citrange $^{\mathrm{x}}$ & 3 & 32 & 114 & 132 & 177 & 154 & 147 & 199 & 154 & 130 & 1243 \\
\hline Minneola $\times$ Trifoliate orange & 19 & 82 & 93 & 91 & 157 & 132 & 137 & 196 & 142 & 78 & 1127 \\
\hline Carrizo citrange & 32 & 70 & 80 & 85 & 121 & 114 & 156 & 186 & 150 & 94 & 1088 \\
\hline $\begin{array}{l}\text { Trifoliate orange } \times \text { Milam } \\
\quad(1572)\end{array}$ & 37 & 57 & 59 & 118 & 127 & 133 & 103 & 153 & 135 & 121 & 1042 \\
\hline Sun Chu Sha mandarin ${ }^{\mathrm{x}}$ & 0 & 5 & 35 & 55 & 69 & 154 & 138 & 220 & 161 & 112 & 950 \\
\hline $\begin{array}{l}\text { Ridge Pineapple } \times \text { trifoliate } \\
\text { orange }(1575-21)^{\mathrm{y}}\end{array}$ & 0 & 0 & 45 & 81 & 77 & 71 & 69 & 114 & 154 & 114 & 730 \\
\hline $\begin{array}{l}\text { Hamlin + Flying Dragon } \\
\text { trifoliate orange }\end{array}$ & 35 & 40 & 62 & 64 & 84 & 67 & 66 & 106 & 67 & 57 & 649 \\
\hline Hamlin $+S$. distich $a^{\mathrm{w}}$ & 34 & 51 & 73 & 75 & 75 & & & & & & \\
\hline $\begin{array}{l}\text { Trifoliate orange } \times \text { Ridge } \\
\text { Pineapple }(1573-26) \text { w }\end{array}$ & 27 & 46 & 40 & 31 & 40 & & & & & & \\
\hline Mean & 32 & 66 & 83 & 104 & 135 & 158 & 147 & 203 & 154 & 122 & 1202 \\
\hline Least significant difference & 15 & 26 & 38 & 41 & 57 & 65 & 57 & 71 & 60 & 60 & \\
\hline
\end{tabular}

${ }^{\mathrm{z}}$ No data were collected at tree age 10 years. Data are sorted according to the 10 -year cumulative yield. ${ }^{\mathrm{y}} \mathrm{N}=3$; planted in Sept. 1991.

${ }^{\mathrm{x}} \mathrm{N}=3$; planted in Mar. 1991.

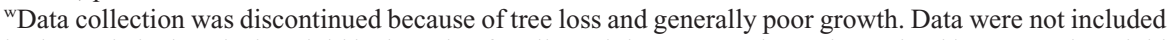
in the statistical analysis. Yield is the value for all surviving trees and was determined by converting yield measured by volume to weight using $38.5 \mathrm{~kg} /$ box as the conversion factor.

for the trees on most rootstocks ranged from 100 to greater than $250 \mathrm{~kg} /$ tree. In many years, statistically significant differences occurred only among the highest and lowest yielding trees. The trees with highest 10 -year cumulative yield were those on the trifoliate orange $\times$ Milam hybrid, $1584(1615 \mathrm{~kg} /$ tree $)$, and C-35 citrange ( $1456 \mathrm{~kg} /$ tree). At the low end of the range were trees on such rootstocks as Carrizo citrange ( $1088 \mathrm{~kg} /$ tree). The differences in cumulative yield among rootstocks were on the order of $50 \%$ to $60 \%$. Differences in yield were not fully explained by differences in tree height because their simple linear correlation coefficient was only $r_{.05}=0.54^{*}$. The strength of the relationship was disrupted by the higher yields of smaller trees like those on C-35 citrange.

Fruit quality. Florida grapefruit are used for the fresh market and processing. Standard quality measurements determine the value of the processed juice as well as maturity for harvesting fresh fruit (Fellers, 1990; Wardowski et al., 1995). Mean juice contents were $63.6 \%$ and $50.6 \%$, soluble solids concentrations 10.2 and 10.1 , acid contents 1.12 and 1.16, and soluble solids-acid ratios 9.2 and 8.8 for when the trees were young (5 years old) or older (9 years), respectively (Table 4). The mean data are typical for Florida grapefruit and the ranges of each variable were small with no exceptional values. However, when those data were combined with yield to calculate soluble solids in $\mathrm{kg} \cdot \mathrm{ha}^{-1}$, the highest values (greater than
$4000 \mathrm{~kg}$ ) when the trees were 9 years old were generally $\approx 1.5$ - to threefold larger than those of the trees with the lower values.

Fruit size. Fruit size distribution data were collected when the trees were 8,9 , and 12 years old. In those years, the mean number of fruit/tree was 386,385 , and 223, respectively, a $58 \%$ difference between trees at ages 9 and 12 years (Table 5). Those 3 years were the year when annual increases in yield stopped ( 8 years) and 2 years thereafter in which the trees on some rootstocks displayed a tendency to alternate bear. Trees on the highest yielding rootstocks produced greater than 450 fruit/tree (Calamandarin, Murcott, and 1584). The trees on 1584 were highly productive in each year, whereas those on many other rootstocks including Murcott and Calamandarin had substantially lower numbers of fruit/tree at age 12 years.

Rootstock and year affected the portion of fruit in each size class but without any significant interactions in the 3 years. Fruit measuring between 92 and $113 \mathrm{~mm}$ represented $\approx 60 \%$ of the total number of fruit/ tree (Table 5). Those sizes are equivalent to Florida commercial sizes 48 to 32 (number of fruit packed in a standard cardboard carton), respectively. For the trees on most rootstocks at each age, the portion of fruit size 48 and smaller was $\approx 10 \%$ to $20 \%$ except at tree age 8 years when the portion generally exceeded $30 \%$. Crop size was not consistently related to the portion of fruit size 48 or smaller. The trees on some rootstocks like Hamlin + Flying 
Table 4. Juice quality ( $\mathrm{n}=6$ ) of 'Marsh' grapefruit from trees on various rootstocks planted in Sept. 1990 in the Florida Indian River region. ${ }^{2}$

\begin{tabular}{|c|c|c|c|c|c|c|}
\hline Rootstock $^{\mathrm{y}}$ & $\begin{array}{c}\text { Tree } \\
\text { age (yrs) }\end{array}$ & $\begin{array}{c}\text { Juice } \\
\text { content }(\%)\end{array}$ & $\begin{array}{l}\text { Soluble } \\
\text { solids } \\
\text { conc. (\%) }\end{array}$ & Acid (\%) & $\begin{array}{l}\mathrm{SSC} / \mathrm{A} \\
\text { ratio }\end{array}$ & $\begin{array}{c}\text { Soluble } \\
\text { solids } \\
\left(\mathrm{kg} \cdot \mathrm{ha}^{-1}\right)\end{array}$ \\
\hline \multirow[t]{2}{*}{ Calamandarin } & 5 & 65.1 & 10.0 & 1.17 & 8.6 & 2615 \\
\hline & 9 & 50.3 & 9.9 & 1.28 & 7.7 & 4746 \\
\hline \multirow[t]{2}{*}{ Murcott } & 5 & 62.3 & 10.2 & 1.25 & 8.2 & 2565 \\
\hline & 9 & 48.2 & 10.2 & 1.34 & 7.7 & 4707 \\
\hline \multirow[t]{2}{*}{ Trifoliate orange $\times$ Milam $(1584)$} & 5 & 65.3 & 9.5 & 1.09 & 8.8 & 2655 \\
\hline & 9 & 51.6 & 9.3 & 1.10 & 8.5 & 4359 \\
\hline \multirow[t]{2}{*}{ C-35 citrange } & 5 & 65.2 & 10.4 & 1.13 & 9.2 & 3772 \\
\hline & 9 & 52.0 & 10.5 & 1.12 & 9.5 & 4319 \\
\hline \multirow[t]{2}{*}{ Minneola $\times$ Trifoliate orange } & 5 & 63.7 & 10.6 & 1.21 & 8.8 & 2246 \\
\hline & 9 & 51.8 & 10.9 & 1.27 & 8.6 & 4164 \\
\hline \multirow[t]{2}{*}{ Norton citrange } & 5 & 62.2 & 10.3 & 1.08 & 9.6 & 2846 \\
\hline & 9 & 51.6 & 10.1 & 1.11 & 9.1 & 3858 \\
\hline \multirow[t]{2}{*}{ Sun Chu Sha mandarin ${ }^{\mathrm{x}}$} & 5 & 62.4 & 9.9 & 1.15 & 8.6 & 1190 \\
\hline & 9 & 50.5 & 10.0 & 1.20 & 8.3 & 3826 \\
\hline \multirow[t]{2}{*}{ Benton citrange $^{\mathrm{x}}$} & 5 & 62.5 & 9.0 & 1.02 & 10.1 & 2951 \\
\hline & 9 & 51.0 & 10.5 & 1.06 & 9.9 & 3649 \\
\hline \multirow[t]{2}{*}{ Swingle citrumelo } & 5 & 64.9 & 10.6 & 1.13 & 9.4 & 2765 \\
\hline & 9 & 49.9 & 10.3 & 1.21 & 8.6 & 3523 \\
\hline \multirow[t]{2}{*}{ Cleopatra mandarin } & 5 & 63.1 & 10.1 & 1.24 & 8.2 & 1582 \\
\hline & 9 & 50.5 & 10.1 & 1.28 & 7.9 & 3403 \\
\hline \multirow[t]{2}{*}{ Carrizo citrange } & 5 & 64.1 & 9.7 & 0.99 & 9.9 & 2052 \\
\hline & 9 & 50.1 & 9.9 & 1.02 & 9.7 & 3287 \\
\hline \multirow[t]{2}{*}{ Ridge Pineapple $\times$ Milam $(1578-173)^{\mathrm{w}}$} & 5 & 63.0 & 9.9 & 1.10 & 9.0 & 2952 \\
\hline & 9 & 48.5 & 10.0 & 1.20 & 8.3 & 3194 \\
\hline \multirow[t]{2}{*}{ Morton citrange } & 5 & 64.7 & 10.6 & 1.11 & 9.6 & 2885 \\
\hline & 9 & 50.6 & 10.3 & 1.11 & 9.3 & 3181 \\
\hline \multirow[t]{2}{*}{ Trifoliate orange $\times$ Milam $(1572)$} & 5 & 62.4 & 10.2 & 1.10 & 9.3 & 2521 \\
\hline & 9 & 49.8 & 9.6 & 1.05 & 9.1 & 2586 \\
\hline \multirow{2}{*}{$\begin{array}{l}\text { Ridge Pineapple } \times \text { Trifoliate } \\
\text { orange }(1575-21)^{\mathrm{w}}\end{array}$} & 5 & 61.9 & 9.6 & 1.10 & 8.8 & 1688 \\
\hline & 9 & 53.3 & 9.7 & 1.06 & 9.2 & 2049 \\
\hline \multirow{2}{*}{$\begin{array}{l}\text { Hamlin + Flying Dragon trifoliate } \\
\text { orange }\end{array}$} & 5 & 64.2 & 10.3 & 1.07 & 9.7 & 1434 \\
\hline & 9 & 51.2 & 10.7 & 1.07 & 10.0 & 1956 \\
\hline Hamlin $+S$. disticha ${ }^{v}$ & 5 & 66.4 & 10.0 & 1.08 & 9.3 & 1808 \\
\hline $\begin{array}{l}\text { Trifoliate orange } \times \text { Ridge pineapple } \\
\qquad(1573-26)^{\mathrm{v}}\end{array}$ & 5 & 59.8 & 11.0 & 1.08 & 10.2 & 619 \\
\hline Mean & 5 & 63.6 & 10.2 & 1.12 & 9.2 & 2310 \\
\hline Least significant difference & 5 & 2.9 & 0.5 & 0.06 & 0.5 & 1193 \\
\hline Mean & 9 & 50.6 & 10.1 & 1.16 & 8.8 & 3594 \\
\hline Least significant difference & 9 & 2.6 & 0.6 & 0.05 & 0.5 & 1373 \\
\hline
\end{tabular}

${ }^{\mathrm{z}}$ Fruit samples were harvested in mid-Feb. 1996 and mid-Mar. 2000 when the trees were 5 and 9 years old, respectively.

yRootstocks are ranked by soluble solids at tree age 9 years.

${ }^{\mathrm{x}} \mathrm{N}=3$; planted Mar. 1991.

${ }^{\mathrm{w}} \mathrm{N}=3$; planted Sept. 1991.

"No fruit were sampled at tree age 9 years.

$\mathrm{SSC}=$ soluble solids concentration; $\mathrm{A}=$ acid .

Dragon trifoliate orange had a relatively high percentage of small fruit every year despite variability in fruit number/tree. The trees on Benton citrange had essentially the same number of fruit/tree when they were 8 and 9 years old, but $34 \%$ and $9.4 \%$ size 48 fruit in those 2 years, respectively. Those and other similar outcomes contradict the concept that fruit size distribution shifts to smaller fruit as crop size increases (Davis et al., 2004).

Whole-tree fruit size distributions rather than individual fruit sizes were compared using PROC FREQ to determine if the trees on certain rootstocks produced crops that tended toward higher proportions of larger or smaller fruit and the approximate magnitude of the difference needed to make that distinction. The outcomes indicated that there were highly significant $(P<0.01)$ differences each year among rootstocks. The mean number of fruit/tree across the entire experiment varied from year to year but appeared not to be a direct factor determining fruit size distribution. The simple correlation coefficients of total number of fruit/ tree compared with the portions of individual fruit sizes were not significant. Therefore, the data of the 2002-2003 season were used for selected pairwise comparisons among rootstocks.

The trees on Hamlin + Flying Dragon trifoliate orange usually had one of the highest percentages of smaller fruit and that was most evident in the 2002-2003 season (tree age 12 years) when the portion of the most desirable 32 and 36 sizes was $\approx 20 \%$ (Fig. 1 ). The fruit distribution of the trees on the somatic hybrid, Hamlin + Flying Dragon trifoliate orange, was skewed toward smaller sizes, whereas those of the trees on Cleopatra and
Sun Chu Sha mandarins, Swingle citrumelo, Carrizo citrange, and others tended toward larger fruit sizes with less than $20 \%$ small fruit. The fruit distribution of the trees on Hamlin + Flying Dragon trifoliate orange rootstocks was significantly different from that of each of the latter rootstocks in the 2002-2003 season. There was no difference between the trees on Cleopatra and Sun Chu Sha mandarins, but each was different from those on Swingle citrumelo and C-35 citrange.

Fruit distributions and economic value. Mean crop value or estimated income/tree summed over three seasons when the trees were 8,9 , and 12 years old was $\$ 305$ U.S. early in the season (November) when FOB prices were higher and \$249 in March when the prices were more typical of the entire season (Table 6). Regardless of the time of year, the crop on the trees on the 1584 hybrid rootstock had the highest value and those on the somatic Hamlin + Flying Dragon trifoliate orange with their large portion of smaller fruit sizes and lower yield had the lowest crop value. Certainly the sustained high fruit number per tree and relatively high proportion of larger sized fruit contributed to the economic performance of the 1584 hybrid.

Highly significant simple correlations of number of fruit/tree and income in each of the three seasons, $r=0.80$ to 0.98 , suggested that yield more than fruit size distribution increased income. The Florida FOB data show that the prices received per carton increase regularly and substantially as size advances from 56 per carton up to size 32 at which point the increment in value for further increases in fruit size is smaller (Table 2). That relationship suggests that trees yielding high proportions of fruit size 36 or larger would be ideal. However, large percentages of desirable fruit sizes do not necessarily equate to large incomes when yield is comparatively low. For example, the mean percentage of size $30+32+27$ fruit was $\approx 52 \%$ for the trees on Carrizo citrange and $38 \%$ for those on 1584 rootstock, but the trees on 1584 had $76 \%$ more fruit (Table 5). Those differences are reflected in the mean March crop value of \$354 U.S. for the trees on 1584 vs. \$210 U.S. for those on Carrizo citrange (Table 6). Trees on other rootstocks like Norton and C-35 citranges had lower percentages of the size 27 and $36+32$ sizes but higher yields leading to higher incomes (Table 5).

Another aspect of fruit size distribution, rootstocks, and prices is the possible impact of seasonal price variability and fruit maturity. There are two questions: first, is there a time in a season when the price of fruit size 27 or larger is so great compared with smaller and medium-sized fruit to favor rootstocks that produce relatively high proportions of larger fruit but with relatively low yield, thus leading to higher crop value? The Florida fresh-market grapefruit season runs from approximately November through April. FOB prices vary seasonally with values being highest at the beginning of the season and 
Table 5. 'Marsh' grapefruit size distribution $(\mathrm{n}=6)$ among trees on selected rootstocks planted in Sept. 1990 and growing in the Florida Indian River region. ${ }^{\mathrm{z}}$

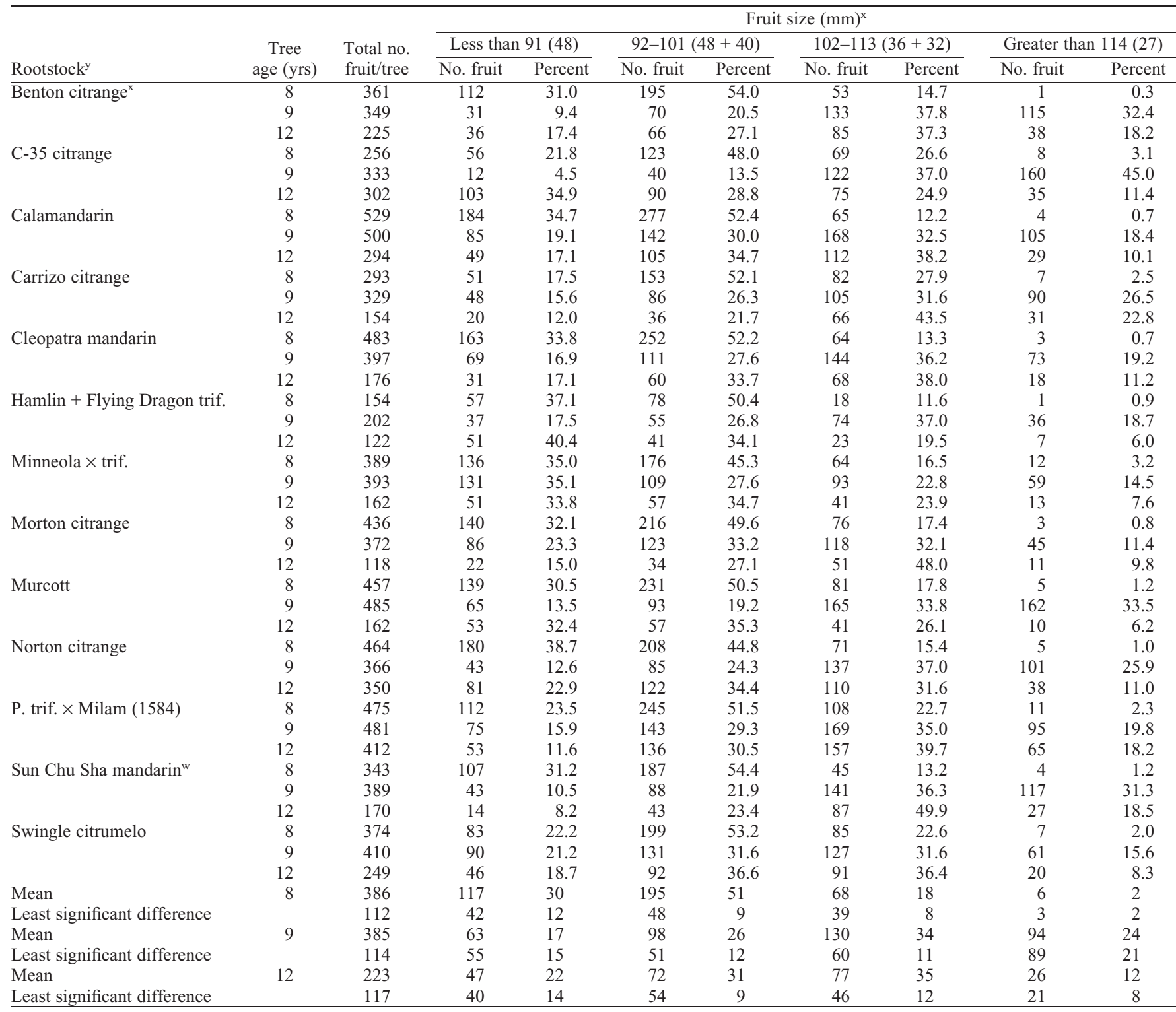

${ }^{\mathrm{z}}$ Measurement dates were mid-Mar. 1999, 2000, and mid-Feb. 2003.

${ }^{\mathrm{y}}$ Rootstocks are sorted by name.

*The fruit sizes, $91 \mathrm{~mm}$ or less, $92-101 \mathrm{~mm} ; 102-113 \mathrm{~mm}$ and $114 \mathrm{~mm}$ or greater are equivalent to commercial sizes of 48 or more, $48+40,36+32$ and fewer than 27 fruit, respectively, packed in the Florida industry standard carton of 0.8 bushels by volume ( $28 \mathrm{~L}$ ), which holds $20 \mathrm{~kg}$ of fruit.

${ }^{\mathrm{w}} \mathrm{N}=3$; planted Mar. 1991.

primarily for the largest sized fruit, which comprise only a small portion of the industry crop (Table 1). In the comparison of crop values (estimated income/tree) early in the season (November) when prices are higher than more typical prices (March), incomes for the trees on all rootstocks were higher in November by $\approx 15 \%$ (Table 6). Therefore, as an example, crop value increased for the trees on Carrizo citrange, but its relative position among the rootstocks was virtually unchanged indicating early-season higher prices for large fruit did not compensate for its lower yield.

The second question is, does rootstock influence fruit maturity and, if so, should the crop value of each rootstock be determined at its optimum harvest time? Rootstock affected fruit maturity based on soluble solids-acid ratio (Table 4). Grapefruit soluble solids:acid ratio increases approximately half a point/ week so a 1-or 2-point difference between rootstocks equates to as much as 2 to 4 weeks difference in maturity. However, fruit maturity, thus, harvesting, is determined by two regulated factors: minimum requirements for soluble solids and juice content according to fruit size (Wardowski et al., 1995). Thereafter, fruit size becomes a major factor. Fruit of size 36 or larger are usually spot-picked at the beginning of the season, then in January, the remaining fruit are harvested. Thus, early maturity would not provide any meaningful financial advantage. Fruit prices are high only for the first few weeks of any season and do not change markedly afterward within a size class. Thus, the use of the more typical March data for comparing rootstock crop values is reasonable.
Rootstock assessments. The desired attributes of orchard systems in Florida have gradually been shifting from widely spaced, large trees to smaller sized, more closely spaced trees (Castle et al., 2010b). Rootstock options have an important role in that shift as well as contributing to other long-standing favorable horticultural traits such as larger fruit size and higher juice quality. Using those traits combined with the estimated incomes to evaluate rootstock performance in this trial, the 1584 hybrid and Norton and C-35 citranges would provide the highest incomes at closer spacing $(\approx 800$ to 1000 trees/ha). The trees on those rootstocks had among the highest income over the 3 years presented, tree height was relatively small, survival rates were high, they consistently produced good fruit sizes and juice quality, 

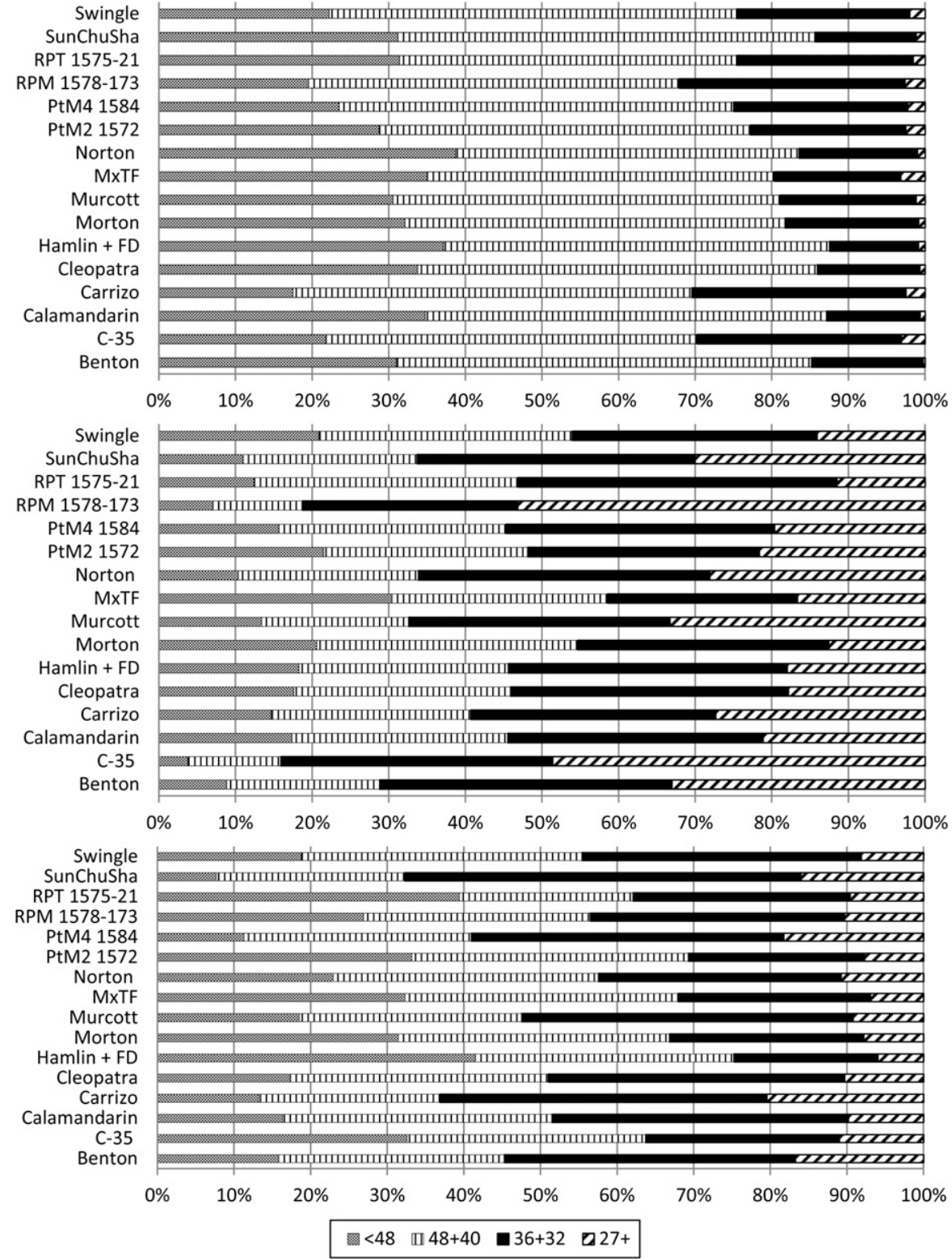

Fig. 1. Whole-tree distribution of 'Marsh' grapefruit in four standard commercial fruit size groups (number of fruit packed in a 20-kg carton) according to rootstock and year: 1998-1999 season (upper panel); 1999-2000 (middle panel); 2002-2003 season (lower panel). For those three seasons, the mean fruit count/tree was 386, 385, and 223 fruit/tree and tree ages were 8,9 , and 12 years, respectively. The percentage distributions are based on measuring the entire crop on each of nine (three replicates) or 18 trees (six replicates)/rootstock (see Table 1 footnotes).

and soluble solids production was relatively high. In addition, fruit shape, although not measured, tended to be more oblate (desired) with thin peel for those rootstocks as observed at harvest time. Among those rootstocks, 1584 was hybridized by Harry Ford (CREC, retired) and has yet to attract commercial attention (O'Bannon and Ford, 1977). It is a poor seed producer. Also, juice quality was not above average in this trial, but was adequate to meet commercial standards. Thus, yield was the critical factor along with fruit size and shape. Norton citrange has been tested in a number of field trials (Castle, 1987; Wutchser, 1979) but also has not achieved commercial status perhaps because of mixed evaluation results. C-35 citrange was released in 1986
Table 6. Estimated cumulative crop value (U.S. dollars) per tree $(n=6)$ of 'Marsh' grapefruit grown in the Florida Indian River region on selected rootstocks when the trees were 8 (1998-1999 season), 9 (1999-2000), or 12 (2002-2003) years old.

\begin{tabular}{lcc}
\hline & \multicolumn{2}{c}{ 3-yr cumulative income } \\
\cline { 2 - 3 } Rootstock & November & March \\
\hline P. trif $\times$ Milam (1584) & 434 & 354 \\
Calamandarin & 391 & 321 \\
Norton citrange & 356 & 292 \\
Murcott & 347 & 283 \\
Cleopatra mandarin & 307 & 253 \\
Swingle citrumelo & 307 & 253 \\
C-35 citrange & 308 & 248 \\
Benton citrange & 303 & 246 \\
Sun Chu Sha & 295 & 239 \\
$\quad$ mandarin & & \\
Morton citrange & 261 & 216 \\
Minneola $\times$ trif. & 260 & 215 \\
Carrizo citrange & 259 & 210 \\
Hamlin + Flying & 136 & 112 \\
$\quad$ Dragon trif. & & \\
Mean income & 305 & 249 \\
Least significant & 42 & 45 \\
$\quad$ differce & &
\end{tabular}

\section{difference}

${ }^{2}$ Incomes were estimated using Freight On Board prices from the Florida Citrus Administrative Committee and for the weeks ending approximately 19 Nov. and 4 Mar. of the same season. The prices are the mean of the 5 years, 2006-2011.

${ }^{y} \mathrm{~N}=3$; planted Mar. 1991.

less vigorous rootstocks. Also, the trees on Calamandarin and Murcott were larger and, thus, would be more suited to more widely spaced orchard designs (250 to 450 trees/ha). Calamandarin was introduced by W.P. Bitters (UC, Riverside; deceased) and has been tested elsewhere in Florida where its traits were as reported herein (Castle et al., 2010a). Murcott is another rootstock that has been tested in field trials partly because of potential benefits from its presumed sweet orangemandarin parentage and its production of very uniform seedling populations (Castle, 1987; Castle et al., 2010a; Wutchser 1979).

The remaining commercial rootstocks include Swingle citrumelo, the most popular commercial rootstock in Florida, one often used for grapefruit, along with Cleopatra and Sun Chu Sha mandarins and Carrizo citrange. The intermediate crop value of the trees on Swingle citrumelo was accompanied by a generally intermediate ranking of their overall horticultural performance. Those results coincide with the general grower and field trial experience with trees on Swingle citrumelo in the Indian River area recognizing that there are limitations to its use in Florida under certain site conditions (Bauer et al., 2005; Castle et al., 1988, 2000, 2010a, 2010b; Youtsey and Lee, 1995). The trees on the mandarin rootstocks, although having a reputation for producing smaller fruit (Castle, 1987; Castle et al., 1993, 2006; McCollum et al., 2002), had intermediate yields with high percentages of larger sized fruit. Those characteristics alone might justify the decades-long commercial use of Cleopatra mandarin as a rootstock for a modest proportion of Florida citrus 
plantings. For grapefruit, Cleopatra mandarin would not be a suitable choice for a modern orchard design primarily because of the large tree size; however, it does have a special purpose use because fruit from trees on Cleopatra mandarin usually have high soluble solids concentration and juice acidity leading to later maturity (Castle, 1987; Wutchser, 1979). Mandarin rootstocks are used commercially to complement trees on other rootstocks to lengthen the harvest season.

In contrast to many of the rootstocks described, the trees on the somatic hybrid, Hamlin + Flying Dragon trifoliate orange, seemed to be the most promising for higher density orchards because of very small tree size, excellent juice quality, and reasonable crops for the tree size. However, they consistently produced mostly small fruit and relatively low yield leading to a low crop value.

Absent from this discussion is a direct comparison of the results to those from trees on sour orange rootstock. However, in another Florida trial with 'Marsh' grapefruit, the trees on several rootstocks including C-35 citrange had higher juice quality than those on sour orange and comparable fruit size based on the mean weight of a sample (Castle et al., 2011).

\section{Conclusions}

There were significant differences among various standard horticultural traits of the trees and fruit of 'Marsh' grapefruit trees grown on various rootstocks in an Alfisol of the coastal Florida flatwoods. When the horticultural outcomes were combined to estimate the crop value, or income/tree, of the fruit sold in the fresh market, crop value summed for three seasons ranged from $\$ 354$ U.S. to \$112 U.S./tree based on March FOB prices. That range in estimated income was primarily the result of differences in yield, not differences in fruit size distribution. Some rootstocks tended to produce crops skewed toward smaller or larger fruit sizes, but those differences were not apparently sufficient to compensate for differences in yield. Based on the current grower interest in smaller sized trees, high yield, and excellent fruit quality, the most promising, highest income rootstocks were those on a new hybrid of trifoliate orange and Milam (1584) and C-35 citrange.

\section{Literature Cited}

Bauer, M., W.S. Castle, B.J. Boman, and T.A. Obreza. 2005. Economic longevity of citrus trees on Swingle citrumelo rootstock and their suitability for soils of the Indian River region. Proc. Fla. State Hort. Soc. 118:24-27.

Bauer, M., W.S. Castle, B.J. Boman, and T.A. Obreza. 2007. Field guide to soil identification for Florida's citrus-growing regions. Univ. Fla. Coop. Extension Publ. SP-362.

Cameron, J.W. and R.K. Soost. 1986. 'C35' and 'C32': Citrange rootstocks for citrus. HortScience 21:157-158

Castle, W.S. 1987. Citrus rootstocks, p. 361-399. In: Rom, R.C. and R.F. Carlson (eds.). Rootstocks for fruit crops. Wiley, Hoboken, NJ.

Castle, W.S. and J.C. Baldwin. 2008. Rootstocks affect the 17-year survival and performance of 'Valencia' trees grown in Immokalee. Proc. Fla. State Hort. Soc. 121:140-144.

Castle, W.S., J.C. Baldwin, and J.W. Grosser. 2000. Performance of 'Washington' navel orange trees in rootstock trials located in Lake and St. Lucie counties. Proc. Fla. State Hort. Soc. 113:106-111.

Castle, W.S., J.C. Baldwin, and R.P. Muraro. 2010a. Rootstocks and the performance and economic returns of 'Hamlin' sweet orange trees. HortScience 45:875-881.

Castle, W.S., J.C. Baldwin, R.P. Muraro, and R. Littell. 2010b. Performance of 'Valencia' sweet orange trees on 12 rootstocks at two locations and an economic interpretation as a basis for rootstock selection. HortScience 45:523-533.

Castle, W.S. and M.G. Bauer. 2005. The 10-year performance and survival of 'Marsh' grapefruit trees on Sun Chu Sha mandarin and various citrumelo rootstocks on Riviera sand, depressional, an Alfisol. Proc. Fla. State Hort. Soc. 118:80-84.

Castle, W.S., K.D. Bowman, J.C. Baldwin, J.W Grosser, and F.G. Gmitter, Jr. 2011. Rootstocks affect tree growth, yield, and juice quality of 'Marsh' grapefruit. HortScience 46:1-8.

Castle, W.S., K.D. Bowman, J.H. Graham, Jr., and D.P.H. Tucker. 2006. Florida citrus rootstock selection guide. Univ. Fla. Coop. Extension Publ. SP-248.

Castle, W.S., R.R. Pelosi, C.O. Youtsey, F.G Gmitter, Jr., R.F. Lee, C.A. Powell, and X. Hu. 1992. Rootstocks similar to sour orange for Florida citrus trees. Proc. Fla. State Hort. Soc. 105:56-60.
Castle, W.S., D.P.H. Tucker, A.H. Krezdorn, and C.O. Youtsey. 1993. Rootstocks for Florida. 2nd Ed. Univ. Fla. Coop. Ext. Publ. SP-42.

Castle, W.S., H.K. Wutscher, C.O. Youtsey, and R.R. Pelosi. 1988. Citrumelos as rootstocks for Florida citrus. Proc. Fla. State Hort. Soc. 101:28-33.

Davis, K., E. Stover, and F. Wirth. 2004. Economics of fruit thinning: A review focusing on apple and citrus. HortTechnology 14:282-289.

Division Plant Industry, Bureau Citrus Budwood Registration. 2010. Annual report. Fla. Dept. Agr. Consumer Serv., Tallahassee, FL.

Fellers, P.F. 1990. Florida's juice standards for grades and their differences from United States standards for grades and United States Food and Drug Administration standards of identity. Proc. Fla. State Hort. Soc. 103:260-265.

Fla. Agr. Stat. Serv. 2010. Florida citrus statistics 2008-2009. Fla. Dept. Agric. Consumer Serv. and U.S.D.A. Agr. Marketing Serv.

Louzada, E.S., H.S. del Rio, M. Setamou, J.W. Watson, and D.M. Swietlik. 2008. Evaluation of citrus rootstocks for the high $\mathrm{pH}$, calcareous soils of South Texas. Euphytica 164:13-18.

McCollum, T.G., K.D. Bowman, and W.S. Castle. 2002. Effects of rootstock on fruit quality and postharvest behavior of 'Marsh' grapefruit. Proc. Fla. State Hort. Soc. 115:44-46.

McCoy, C.W., W.S. Castle, J.H. Graham, J.P. Syvertsen, and R.J. Stuart. 2004. Pesticide suppression of Diaprepes abbreviatus (L.) (Coleoptera: Curculionidae) promoted differential growth and survival of 'Hamlin' orange trees budded to five rootstocks in a Phytophthora infested grove. Proc. Fla. State Hort. Soc. 117: 167-173.

O'Bannon, J.H. and H.W. Ford. 1977. Resistance in citrus rootstocks to Radopholus similis and Tylenchulus semipenetrans (Nematoda). Proc. Int'l Soc. Citricult. 2:544-549.

Obreza, T.A. and K.T. Morgan (eds.). 2008. Nutrition of Florida citrus trees. $2^{\text {nd }}$ Ed. Univ. Fla. Coop. Ext. Publ. SL-253.

Rogers, M.E., M.M. Dewdney, and T.M. Spann (eds.). 2012. Florida citrus pest management guide. Univ. Fla. Cop. Ext. Publ. SP-43.

Stover, E. and W. Castle. 2002. Citrus rootstock usage, characteristics, and selection in the Florida Indian River region. HortTechnology 12:143-147.

Wardowski, W., J. Whigham, W. Grierson and J. Soule. 1995. Quality tests for Florida citrus. Univ. Fl. Coop. Extension Bull. SP-99.

Wutchser, H.K. 1979. Citrus rootstocks. Hort. Rev. 1:237-269.

Youtsey, C.O. and O. Lee. 1995. A 6-year comparison between 16 rootstocks budded with 'Hamlin' sweet orange. Proc. Fla. State Hort. Soc. 108:69-73. 